\title{
Trade-Growth Nexus in Landlocked Developing Countries: A Quantile Regression Framework
}

\author{
Ramesh Chandra Paudel ${ }^{1}$
}

\begin{abstract}
This paper investigates the trade growth nexus in landlocked developing countries. Landlockedness imposes exogenous costs to a country making import more expensive and exports uncompetitive. Despite this fact, landlocked countries also are in the process to be integrated with world but in slow pace. Initial income is one of the major determinants of economic growth in these countries whether they are poor or rich now, however, negative impact of Landlockedness seems more severe in economic growth of poor countries. Trade has a positive role in landlocked countries too to foster their growth, but mostly rich landlocked countries are benefited from trade than the poor countries. Neighbour countries' economic growth has played a significant role in landlocked countries. As the country's income level increases, it shifts towards industrialisation so that capital formation is more important compared to labour force until the economy converges to the developed economy.
\end{abstract}

Key words: Trade policies, Economic development, Economic growth. JEL Classification Codes: F14, N10, O40.

\section{Introduction}

There seems a strong nexus between trade and economic growth. Because of this nexus, trade is explained as an engine of economic growth in the literature. Also, trade-growth nexus has become one of the crucial issues in macroeconomics and has got the numerous attentions in the context of developed and developing countries. However, it has not been examined in context of landlocked countries separately. It is being increasingly difficult to ignore the issues faced by landlocked countries to enhance their economic growth as the number of landlocked countries is increasing.

In the history of development economics, trade has been thought of as a key element to economic growth. It is also known as the symptom of prosperity and tool to upgrade the living standard of people. The landlockedness is an additional barrier that imposes exogenous costs to participating in international trade and hence reducing growth performance of a country. The history of economic growth suggests that landlocked countries have grown much

1 Dr. Paudel is visiting fellow at the Australian National University, Canberra, Australia, Email: ramesh.paudel@alumni.anu.edu.au 
more slowly than coastal accessed countries in $20^{\text {th }}$ century. At present, there are total of 43 landlocked countries and out of which 34 countries are recorded as developing countries, mostly low income, lower middle income and few upper middle-income countries.

The real fact is that none of the landlocked countries outside the European region have been known as the developed countries yet. The reason seems to be clear that the involvement in world trade for landlocked countries is very tough because of transportation and transit costs that make their import more expensive; on the other hand, their exports remain uncompetitive as they have to use the neighbours' infrastructure for the international trade (Paudel, 2013). This situation creates a doubt that how trade has played role in the economic growth of landlocked developing countries? This paper aims to answer this research question.

The landlocked countries with the bad neighbour (low economic performer with poor governance system) are suffered adversely for their trade and economic development; however it had not conducted any empirical analysis to test this hypothesis (Collier, 2007). The issue is important due to various reasons. Firstly, landlocked developing countries are standing far behind compared to others in every aspect of development. It seems to be very hard to solve these issues themselves. Without the proper growth in these countries, the desire of the world 'Peace and Prosperity' is impossible in this era of globalisation. Both bad and good impact spill over quickly to other countries in this era; such as high technology of the developed countries is providing many opportunities to developing countries. On the other hand, poverty in African and some Asian countries is challenging the world. Secondly, most of the developing countries are suffered with bad governance, which is synonym of the adverse consequence of the poverty and poor internal management. Focusing on the good governance in those countries makes easy to bring them out of poverty trap and contribute to make a prosperous world. Hence, promoting efficient transit system to reduce transaction costs should be an important objective of the current activities (UNCTAD, 2006).

There are some studies as discussed in the literature review that highlight the problems faced by landlocked countries. The major consensus from the literature is that landlockedness reduces the economic growth due to exogenous costs involved in trade. For example, landlocked countries naturally face the problem of slower economic growth (MacKellar et al., 2000; \& Paudel, 2014).

This study contributes in the literature mainly in three ways; firstly, it is the first study in the literature to analyse the trade growth nexus focusing only on landlocked developing countries; secondly, it contributes in the methodological approach proposing to analyse the neighbourhood impact on the growth model for landlocked countries as the literature lacks this framework to study the economic growth of landlocked countries.

The organisation of this paper is as follows; the next section presents the overview of landlocked countries focusing on trade and economic growth performance; section 3 presents the literature survey covering trade-growth nexus literature and studies about the economies of landlocked countries; section 4 presents the research methodology covering data sources, variable description, hypotheses, and model; section 5 presents about the quantile regression framework; section 6 presents the empirical results and interpretation; and the final section presents the conclusion and policy inferences. 


\section{Trade and Economic Growth in Landlocked Countries: An Overview}

Out of total 214 countries as recognized by World Bank, 34 countries landlocked developing countries, which must rely on theirs neighbours for international trade. As a result, these countries suffer by high transportation costs and loose business consignment due to unreliability of their supply chain. Export trade in this sense remains not only expensive to them, but also their trade becomes unreliable and hence uncompetitive. Because of this situation, landlocked developing countries have low economic performance.

\section{Economic Growth Performance}

The average growth rate of all landlocked countries since 1960 to 2009 is recorded approximately 3.6 percentage compared to 4.1 percentage of non-landlocked countries based on World Bank (2011) database. The situation was worst before 1990 because the landlocked countries grew by an average of percentage lesser than coastal countries for the duration of 1965-1990 (Hailou, 2007). This clearly shows that landlockedness is additional barrier for economic growth to the landlocked countries, and for landlocked developing countries this adverse impact can be even higher. Figure 1 shows the real per capita GDP of non-landlocked countries, landlocked countries and world's average. Landlocked countries' average real per capita GDP lower than the non-landlocked countries

Figure 1: Real Capita GDP

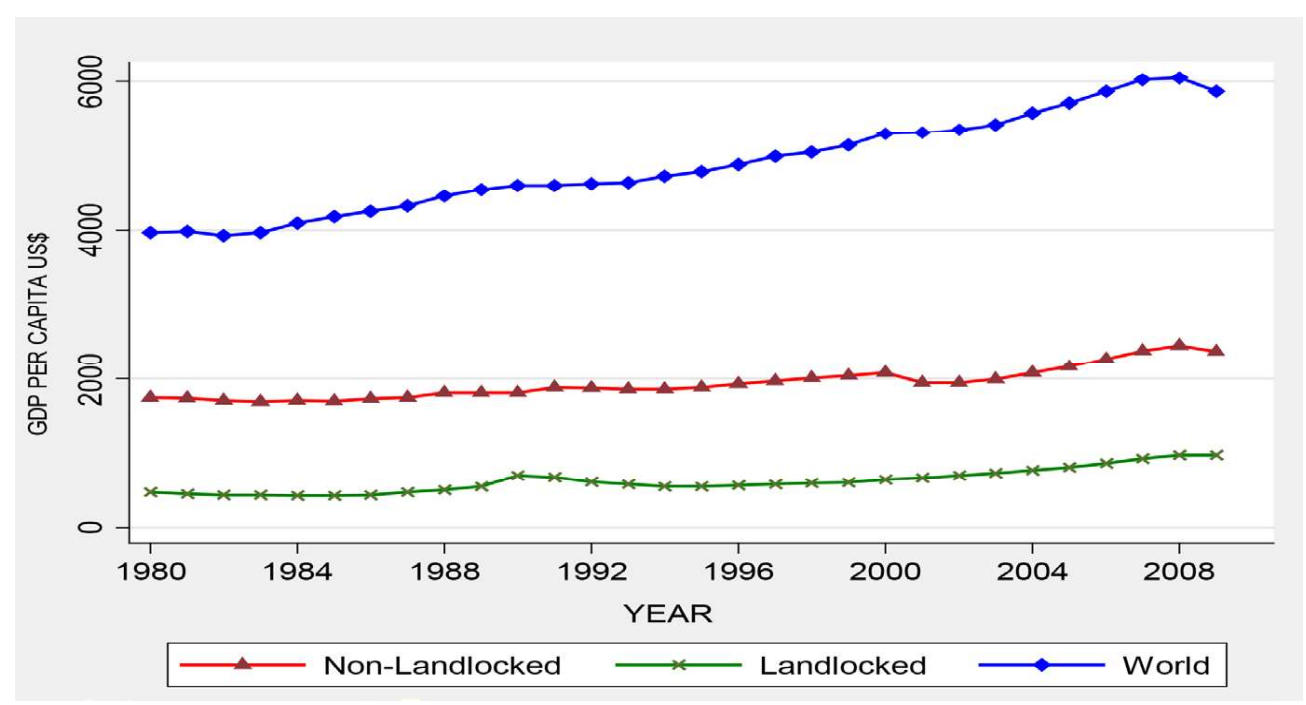

Source: Graphed from the World Bank (2011) data.

Figure 2 shows the clear distinction between two types of developing countries, which have very low real per capita GDP. Landlocked developing countries have average of less than $\$ 1000$ compared to far above than $\$ 2000$ in other developing countries in 2009 . Due to high per capita income in high income countries, the world's average is far above than that of these developing countries. The bend in the curve in year 2008 onward is because of global financial crisis (GFC) that has greater impact in high income countries and other developing 
countries as indicated by the series. GFC's impact was nominal in case of landlocked developing countries due to lower level of integration with the world's major markets.

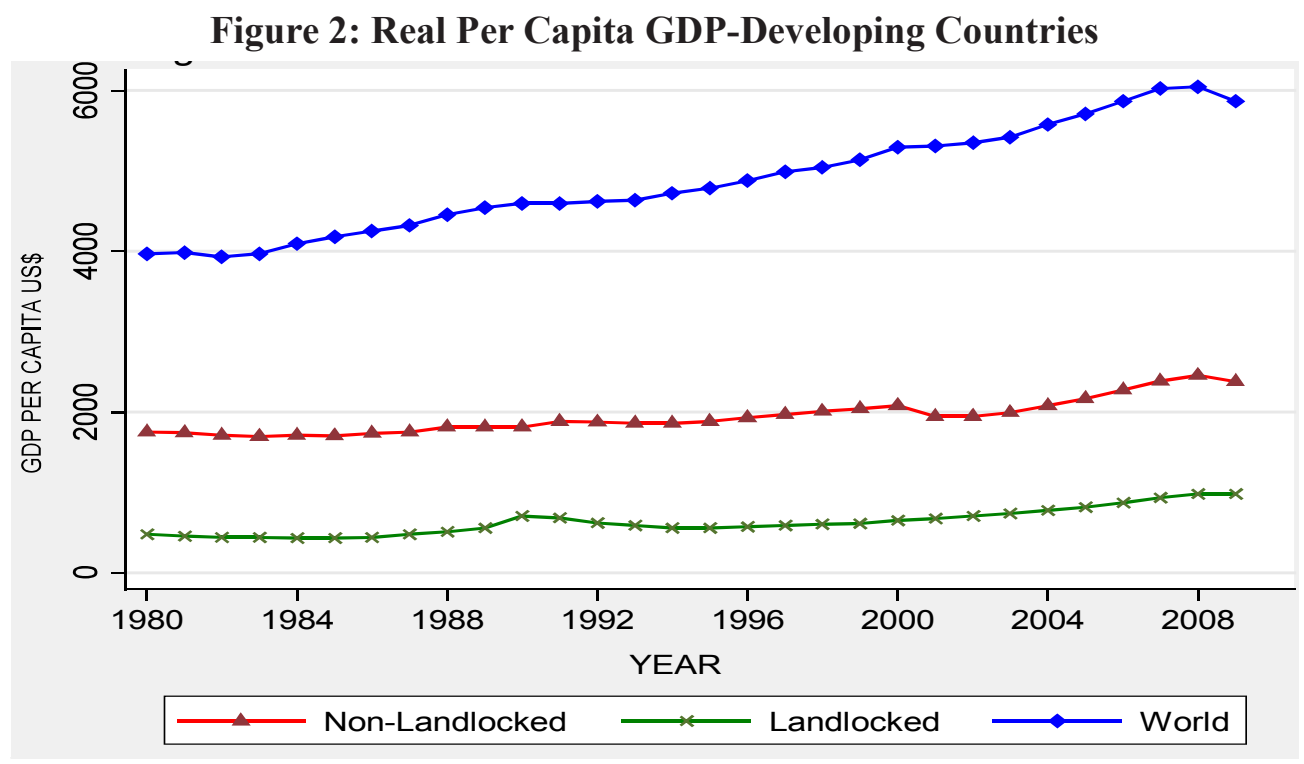

Source: Graphed from the World Bank (2011) data.

\section{Trade Performance}

Trade is explained as an engine of economic growth in the literature. The importance of international trade is increasing day by day in this era of globalization. If we analyse the international trade of 34 landlocked developing countries, which have only about 1 percentage of world's trade and no doubt that it has been import dominancy, however the magnitude is not big. The reason to happen such a low performance of trade in developing countries is trade costs because the amount trade costs is the key to explain the major problems in international trade making trade more expensive and uncompetitive (Obstfeld \& Rogoff, 2000).

Figure 3 shows the exports of both types of developing countries for the years 1980, 1990, 2000 and 2009. Total exports and imports of developing countries for these years seems to be very negligible difference, but there is a huge gap of both exports and imports between landlocked and non-landlocked developing countries. As explored by Figure 3, total exports from non-landlocked developing countries in 1980 were $\$ 330$ billion compared to $\$ 8.5$ billion of landlocked developing countries; and it reached to $\$ 4.44$ trillion for nonlandlocked developing countries and $\$ 1.88$ billion for landlocked developing countries in 2009. The average annual growth rate of exports for the entire period (from 1980 to 2009) in non-landlocked countries recorded 10.2 percentage compared to 14.63 percent in landlocked developing countries but the volume is significantly low due to very small initial values. Basically, there is a huge jump in exports of non-landlocked countries from 1990 showing that these countries are well benefited with the globalisation process, while reverse situation is found for the landlocked developing countries, which are not integrated with the world 
economy. The gap is widening even the number of landlocked developing countries is increasing. Figure 4 also shows a similar trend in imports of developing countries' category.

Figure 3: Exports-Developing Countries

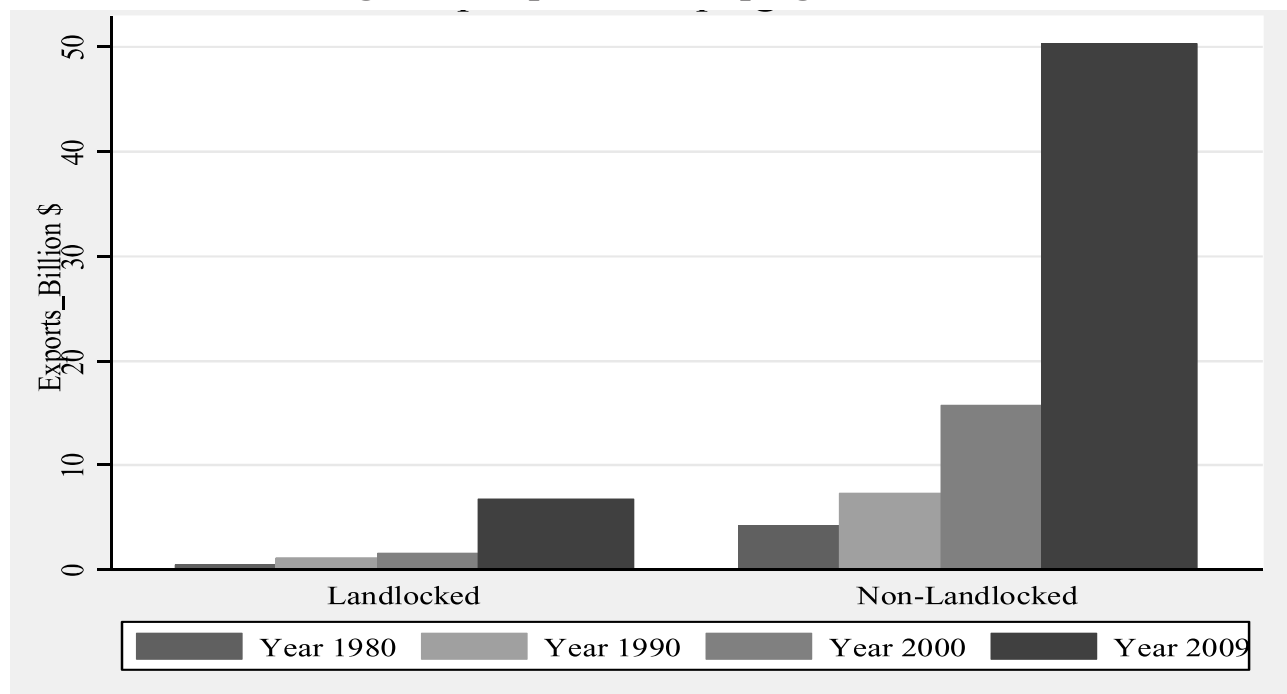

Source: Graphed from the World Bank (2011) data.

Overall trade performance of landlocked developing countries is more deprive than the trade performance of non-landlocked developing countries. It seems that due to the high trade costs, these countries are not well integrated with rest of the world to get the trade benefits from globalisation. However, the trade performance (both import and export) of nonlandlocked developing countries has been increased notably since 1990.

Figure 4: Imports-Developing Countries

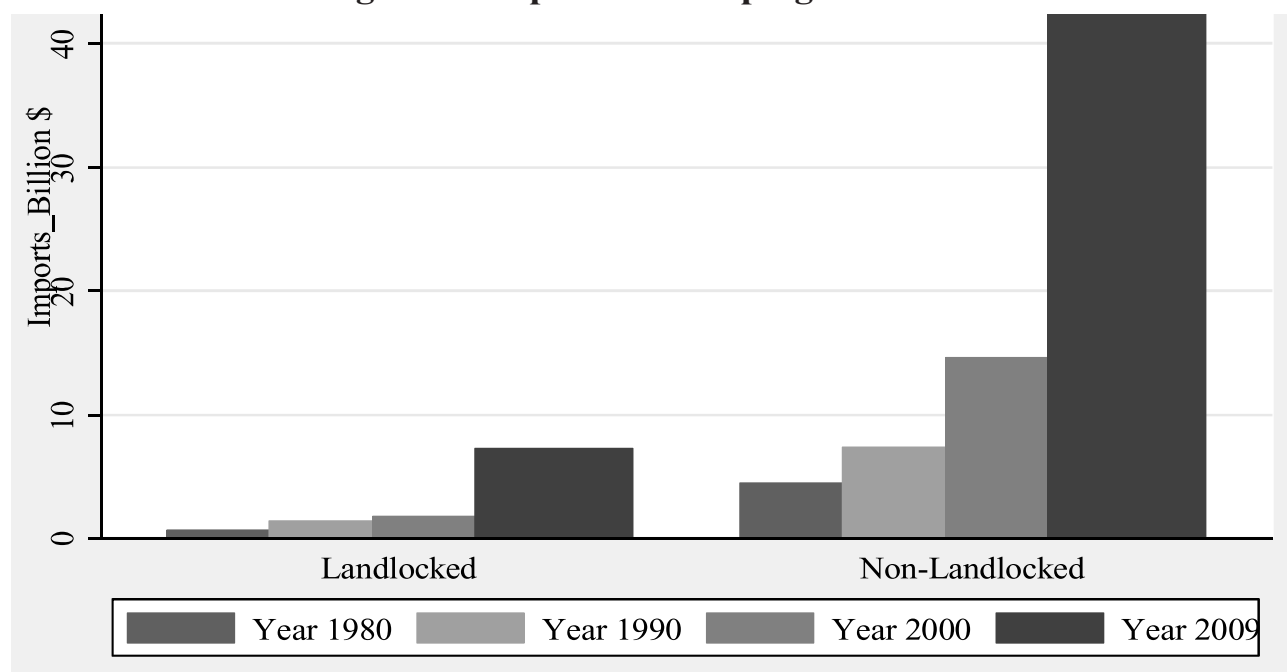

Source: Graphed from the World Bank (2011) data. 
6 | The Economic Journal of Nepal (Issue No. 151)

\section{Trade-Growth Nexus}

Trade-growth nexus shows how these two important economic variables move together. Particularly, interesting things here is how this nexus is being developed in two categories of developing countries. This relationship explains the contribution of trade in economic growth. In Figure 5, it is visible that the developing countries seem to be more reliable in trade even it is not profitable as they have no other major sources of income; on average almost 77 percentage of GDP comes from trade in non-landlocked developing countries for the period from 1980 to 2009, while for the landlocked developing countries this figure seems to be around 73 percentage of GDP compared to that of the world around 43 percentage for the same period.

The figure 5 shows that the trade has contributed more in GDP of landlocked developing countries since 1993. However, we see the fluctuation. But before 1993, non-landlocked developing countries' share was clearly more than that of landlocked developing countries; and it has been declined from 2008 for all categories. The concluding point is that the contribution of trade in GDP for the world and landlocked developing countries have been increased in overall duration, while for the non-landlocked countries remains almost similar phase of 1980

Figure 5: Trade GDP Relation in Developing Countries

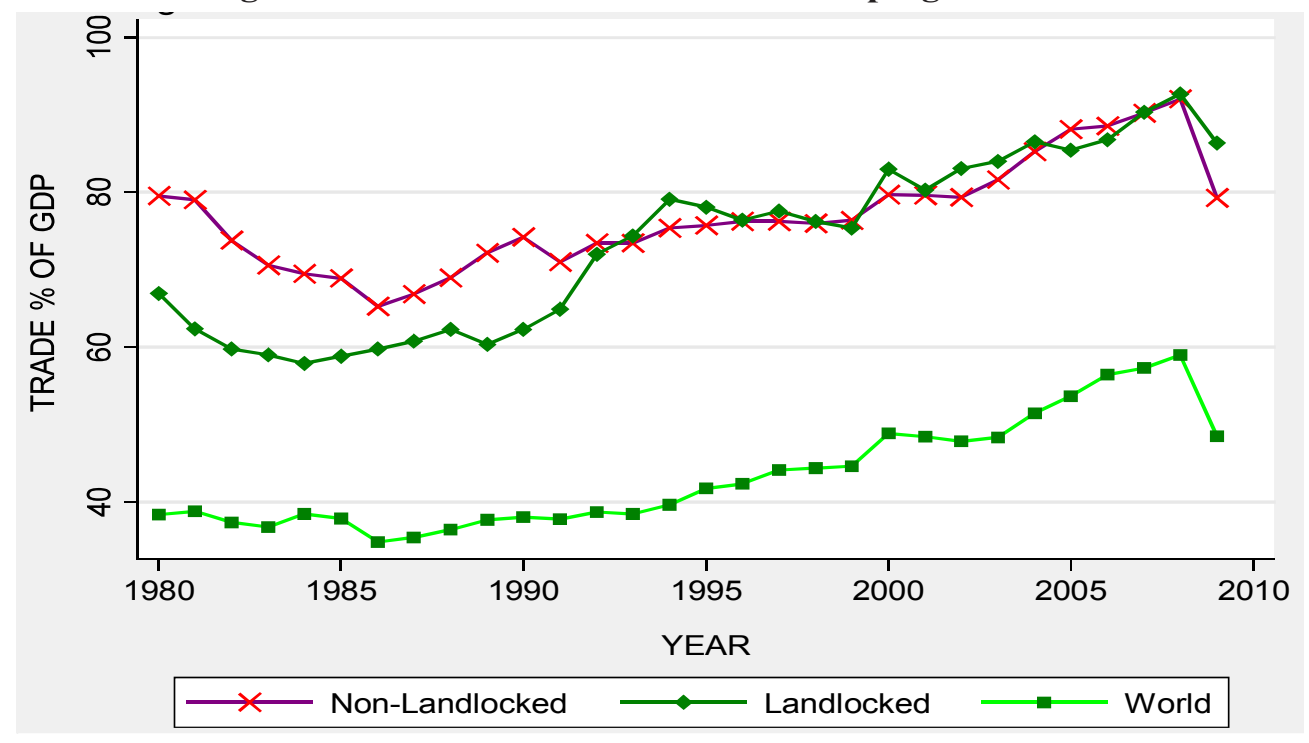

Source: Graphed from the World Bank (2011) data.

\section{Brief Literature Survey}

\section{Theoretical Framework: Landlockedness, Trade, and Growth}

Informally, the role of the trade in economic development was discussed in the Kautilya's era (Waldauer, Zahka, \& Pal, 1996), though formally it begins from classical growth theory as Adam 
Smith correctly pointed out that trade boosts the national income. The issue of landlockedness is almost ignored in theoretical economic growth literature. All the landlocked countries have to trade via their neighbours unless they use air transport but doing so is comparatively expensive losing the trade competitiveness. Another part of the story is that these countries are suffered in trade and overall economic growth aspects due to economic inefficiency of their neighbours in many ways. If the landlocked countries' neighbour is growing slowly it impacts the landlocked country's economic growth adversely mainly in three ways; firstly, they are suffered due to the low quality bureaucratic administration that compels them many unexpected trade expenditure; secondly, neighbours have poor trade infrastructure that creates supply chain unreliability so that any trading partners do not feel safe trading with these countries; and thirdly; as these countries have to cross other countries' boarders for trade, need to bear heavy amount of transportation costs due to long distance. Therefore, the trade volume in these countries seems very low compared to non-landlocked countries. In this background, 34 out of 43 landlocked countries are developing countries facing the problem with slow growth.

Bhagawati (2000) suggests that trade is engine of economic growth. But from the literature it is found that the issues of trade and growth performance in landlocked developing countries have not been investigated systematically focusing inter-country differentials. Quality human resources, education, technological advancement, saving and investment, infrastructural development transform the economy from subsistence economy into commercial economy and finally into technology based economy that helps to reduce the poverty and results the economic development (Sachs, 2008).

\section{Empirical Analysis: Landlockedness, Trade and Growth}

Trade and economic growth are probably the most discussed and widely covered variables in empirical literature of the development economics. The focus of international trade until 1970s was import substitution and since then focus is shifted to export orientation or outward looking trade policy. There are notable arguments in and against the role of trade in economic growth. The debate some time seems to be like chicken and egg debate i.e. trade causes economic growth or economic growth causes the trade.

The literature in trade and growth relationship is divided in 2 major categories; such as trade has negative relation with growth and trade has positive relationship with growth. In some cases, the relationship is ambiguous. One thing is clear, that is, the role of trade in 200 years ago was not as important as it is today, and the role of trade is increasing rapidly during the globalisation process.

Landlockedness has been used as an explanatory variable in growth regression and the results generally suggest a significant negative impact in growth. But no one has so far probed this negative impact through a systematic analysis focussing on inter-country differences among landlocked countries in growth performance. A notable conclusion can be reached with the help of some works such as Foreman-Peck (1995) and Vamvakidis (2002) state that trade openness and economic growth had negative relationship before a 
century. Contrary to this view, trade has contributed significantly in economic growth in the recent decades in different countries, region and context (Bhagawati, 2000; Clemens $\&$ Williamson, 2004). There are various ways where trade contributes to enhance economic growth, but the conclusive vision can be found as in Kalirajan and Singh (2008) that states 'trade with exports friendly policies contribute significantly in economic growth'. Almost similar findings were concluded in Paudel (2016).

Generally, the empirical studies are of 2 types; first, make econometric analysis using time series models with various methods such as co-integration and regression analysis, univariate and multivariate analysis. The trend of time series methods is changing over time i.e. most studies performed 1960s and 1970s used unconditional correlation and static regression analysis such as Kravis (1970) and Voivodas (1973). On the other hand, standard regression models assume all regressors to be exogenous and predict unidirectional causality, i.e. from trade to growth and ignore the reverse causality that is from growth to trade. Similarly, this method started to estimate the static model level to dynamic models considering the first difference until late 1980s. Since 1980s, the most studies started estimating the long run models testing the unit root features of time series and applying more efficient co-integration test with error correction model (ECM).

Most studies conducted since 1990s, the trend to make co-integration analysis taking consideration of structural change is found significantly. In the time series analysis, mostly the country specific studies are made, and findings are of diverse ranges with positive, negative and neutral association with growth. The second method is cross countries and panel data analysis widely used since 1990s and is still popular. Basically, the focus of these studies is exports, trade openness, tariff rate reduction and manufacturing output, and global product sharing network.

\section{Determinants of Economic Growth}

There are various aspects covered in the growth theories, however, unique answer is not obtained yet. Classical growth theory focuses on free market economy and believes that trade enhances economic growth. Neo classical growth theory adds more elements as the contributor of economic growth such as; capital stock, factors of production, investment, technology and human capital. Endogenous growth theory believes that technological innovation enhances the productivity to accelerate the economic growth. These developments in economic growth theories show that economic growth literature is vague, and also the focus is different.

The findings are not similar, which seems natural because all countries or regions are passing from different phases of development and their contributor for the economic growth are also different. Similarly, it can be said that their development paths are not similar. For example, industrialisation resulted economic growth in Japan, but it is not the case of Australia; and the determinants of economic growth in German is quite different than the growth determinants of Nepal or other small and landlocked countries. Ram (1985) argued that the exports can motivate for the higher level of output employing labour and capital. The exports may lead to a more efficient allocation of resources in terms of comparative 
advantage and production efficiency so that economic growth can catch the momentum.

Dufrenot et al., (2010) pointed out that the effects of openness on growth is higher in low growth rate countries compared to high growth rate countries. Barro (1999) analysed the determinants of economic growth and concluded that better maintenance of rule of law, lower inflation, smaller government consumption, and initial level of GDP. At the initial level, political rights also influence the growth but tend to retard after moderate level of democracy is obtained. Export performance of East Asian countries and China shows that a country with more open trade policy boosts the export performance as they can benefit from the production sharing network and increase the national output in a nation (Athukorala, 2011). Price of investment goods, distance to major world cities, growth promoting policy strategies, access quality to international markets and institutional reforms are the determinants of economic growth as pointed by Moral-Benito (2009).

Temple (1998) attempted to identify adverse effects of bad policy outcomes in African countries considering initial conditions that account more than half of the variation in developing countries growth rates, using least trimmed squares method in cross country data. Temple explored that even good policy may not give the desire results in the absence of good initial conditions. Developing countries with relatively low social capital have bad policy outcomes resulting low investment and growth. Initial condition plays significant role to model the policy outcomes, and social capital is the most important initial condition for economic growth. Awokuse (2008) investigated the contribution of trade openness on exports and imports to accelerate the economic growth and found that export promotion with import constraints may not contribute sufficiently to economic growth. It shows that trade openness both in terms of export and imports are important for international trade to fruit the economic growth. But the question rises how far we should go for the magnitude of the liberalization to improve the export performance. One finding from Weiss (1999) and Paudel \& Jayanthakumaran (2009) suggest that the greater the magnitude of the trade liberalization provides the better performance of the export performance indicators, which are revealed comparative advantage measure of net trade balance, efficiency wage estimates of unit labour cost, total factor growth and export growth.

Transportation cost is the major obstacle for trade in landlocked developing countries. Transportation cost includes the transit cost. Money cost includes the variety of charges by the transit countries i.e. customs, road charges, checking costs, loading and unloading costs in different occasion plus hidden cost paid to the employees and authorities of the transit countries. Business cost is the one that results to delay the carrying system and creates the very unpredictability in the transportation and supply chain system, because of this, the trade becomes very fragile and vulnerable. Gallup et al., (1999) also focused this importance aspect in order to boost the economic growth in landlocked developing countries.

From the brief literature survey, four notable points are found like - (i) landlockedness deters the trade due to high transportation costs and hampers economic growth; (ii) In most of the cases, trade has strong positive association with economic growth and economic development; (iii) the determinants of economic growth are not unique in every country and there are ranges of determinants, however trade openness, export performance, labour force, capital formation are most common; and (iv) neighbourhood impact has not yet been analysed in any studies. 
10 | The Economic Journal of Nepal (Issue No. 151)

Therefore, developing a specific framework to study the trade and economic growth nexus with focus on neighbourhood impact on landlocked developing countries is an important issue and the study wants to contribute in this regard.

\section{Hypotheses}

Existing literature lack a depth analysis on trade growth nexus in landlocked countries. The study aims to bridge this gap by investigating the growth constraints associated with landlockedness employing suitable methodological approach so that a good policy inference can be made. For this, three hypotheses are formed to analyse the trade and growth aspects of landlocked countries:

$\mathrm{H}_{1}$ : There is positive nexus between trade and economic growth in these countries despite the harassment caused by landlockedness in trade.

$\mathrm{H}_{2}$ : Economic growth of neighbour countries impacts positively to the economic growth of landlocked countries.

$\mathrm{H}_{3}$ : Initial income level plays more important role in poor countries than in rich countries.

\section{Research Methodology}

\section{Source of Data, Study Period, and Tools of data Analysis}

The data suitable for the model are collected from World Bank (2011) database for all 43 landlocked countries and their neighbours and then compiled as unbalanced panel structure covering the period from 1990 to 2009. The model is tested using ordinary least square (OLS) regression considering the fixed effect, random effect, and quantile regression procedures. Then, the robustness check is conducted with restricted models and excluding high income countries.

\section{Model a nd Variables Specification}

To test given hypotheses, a simple growth model as developed in Islam (1995) has been applied with extension of explanatory variables, which includes 5 major concern variables with following specification:

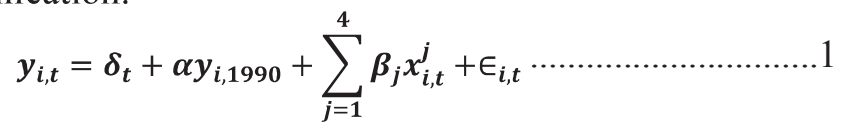

Where, dependent variable is per capita GDP growth rate, and explanatory variables include the initial income level which is proxied by the log of real per capita GDP of the year 1990 (ININCOM), $\mathrm{X}$ is the vector of rest of explanatory variables. Total trade to GDP percentage (TRADE), labour force growth rate (LFG), foreign direct investment inflow to GDP percentage (FDINFLO) and log of economic growth of neighbour countries (LNBREG) and gross capital formation to GDP percentage (GCF) are included in the $\mathrm{X}$ vector. Robustness check is performed in two ways, (i) restricting the model removing GCF in the X vector and (ii) removing the highincome countries for both unrestricted and restricted models. Similarly, is a constant term and 
is the error term which is assumed that it has a normal distribution. The sign of all in the vector $\mathrm{X}$ are expected to be positive. Trade GDP percentage represents the openness variable and most of the empirical evidence suggest that it has the positive association with the economic growth, i.e, dependent variable. If it is similar in this study too, it will support to the first hypothesis.

The variable LNBREG is in the natural log form of NBREG, which is constructed as in equation (2) and represents the economic growth of neighbour countries, which is assumed to impact positively to the economic growth of landlocked countries. Because, the economic growth in neighbour countries brings better trade infrastructure and makes more reliable supply chain in the neighbour countries, which are also the transit countries. It facilitates better opportunities for international trade and impacts the economic growth of landlocked countries. Hence, the positive sign of economic growth of neighbour countries would mean it helps to boost the economic growth of landlocked countries; and support our second hypothesis. The high magnitude of initial GDP in lower quantile countries would support the third hypothesis. The growth in labour force contributes to increase the output and hence the per capita GDP growth, thus expected positive sign in the model. Similarly, gross capital formation and foreign direct investment (FDI) raise the total amount of capital for the investment and by that to enhance the per capita GDP growth, thus expected to have positive sign.

In this model, economic growth of neighbour countries variable is constructed with the average growth of all individual landlocked country's neighbour countries. So, neighbour growth is:

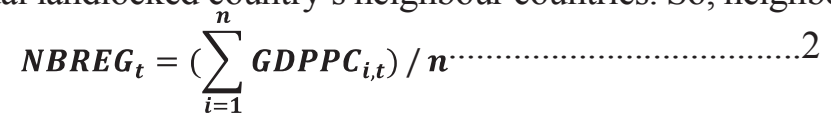

Where, $\boldsymbol{t}$ represents the year and $\boldsymbol{n}$ represents the number of neighbour countries, and is real per capita GDP.

\section{Quantile Regression Framework}

Most of the current empirical analysis in economics are based on average value of the sample data and the method used in trade growth nexus are dominated by cross section data using OLS and instrumental variable (IV) regression analysis as discussed in Billmeier and Nannicini (2007). The main drawback in this method is, OLS assumes homogeneous elasticity across countries, which is not correct if the sample includes different subsets of countries as in this study; such as low income, lower middle income, upper middle income and high income countries; where outliers are difficult to remove from the model and it may lead to heterogeneity bias in underlying data. Therefore, quantile regression based on median value in the linear model improves this problem and helps to analyse the determinants of growth in different subsets of countries as it presents the estimates for different quantiles in order to analyse the role of specific variable on growth of different subset of countries. More clearly, labour force growth may have stronger role in developed countries compared to developing countries, and the role of FDI may be different in poor and rich countries. These differences are not addressed in OLS.

Koenker and Bassett (1978); and Buchinsky (1998) have explained the model. Let $(=1,2 \ldots \ldots . . \mathrm{T})$ is a random sample of random $\mathrm{Y}$ with distribution function $\mathrm{F}$, and $\theta^{\text {th }}$ sample quantile, $0<\mathrm{q}<1$ so that the minimization problem appears in the following form: 
12 | The Economic Journal of Nepal (Issue No. 151)

$$
\min _{\mathrm{b}}\left[\sum_{t, Y t \geq b} \theta\left|\mathrm{y}_{\mathrm{t}}-\mathrm{b}\right|+\sum_{t, Y t<b}(1-\theta)\left|\mathrm{y}_{\mathrm{t}}-\mathrm{b}\right|\right]
$$

For the $\theta^{\text {th }}$ quantile, the specification of the model will be in the following form:

$$
\begin{gathered}
\min _{\mathrm{b}}\left[\sum_{t, Y t \geq b \mathrm{x}_{\mathrm{t}}} \theta\left|\mathrm{y}_{\mathrm{t}}-\mathrm{b} \mathrm{x}_{\mathrm{t}}\right|+\sum_{t, Y t<b \mathrm{x}_{\mathrm{t}}}(1-\theta)\left|\mathrm{y}_{\mathrm{t}}-\mathrm{bx} \mathrm{x}_{\mathrm{t}}\right|\right] \\
=\min _{\mathrm{b}} \frac{1}{\mathrm{~T}} \sum_{\mathrm{t}=1}^{\mathrm{T}} \rho_{\theta}\left(u \theta_{\mathrm{t}}\right)
\end{gathered}
$$

Where, $\rho \_\theta(\lambda)=\theta-\mathrm{I}(-\lambda), \lambda$ is check function and $\mathrm{I}($.$) is usual indicator function.$

\section{Empirical Analysis and Results}

The empirical analysis results are obtained with two methods. First, the model has been tested for normal process to adopt the fixed effect (FE) analysis conducting 'Housman' test and the high value of correlation reported in Table 1 also confirm that the decision of choosing FE is correct. Second method adopted is quantile regression and the results are reported in Table 1. The upper panel of table 1 reports the unrestricted model for all landlocked countries with FE and quantile methods. The results indicate that initial income level, trade, neighbours' economic growth have significant positive impact on economic growth of these countries, however foreign direct investment and capital formation have not played significant role in landlocked countries in overall.

The FE results support both hypotheses conforming that there is positive association of trade and growth in landlocked countries despite the harassment caused by landlockedness; and neighbour countries' economic growth impact significantly to the economic growth of landlocked countries. The quantile regression results conforms our third hypothesis; initial income plays more significant role in poor countries compared to rich countries i.e. 1 percentage increase in initial income causes the low income countries to grow by about 0.50 percentage, middle income countries by about 0.40 percentage and high income countries by about 0.20 percentage; this results support Temple (1998) in the role of initial income.

The FE results explore that one percentage increase in initial income has led to increase the economic growth by 0.27 percentage. Trade has very low magnitude but significant role indicating 1 percentage increase in trade results to increase the economic growth by 0.02 percentage, neighbours' economic growth is measured in natural logarithm form and has a very high magnitude indicating 1 percentage increase in neighbours' economic growth leads to increase the economic growth by almost 2.5 percentage. The labour force, which is main factor of production in low income countries, shows that 1 percentage increase in labour force causes the economic growth to foster by 0.87 percentage.

The quantile regression results tell a real story; only landlocked developed countries are benefited by their neighbours' economic growth significantly. Another important finding from quantile regression result is trade has played significant role in landlocked countries, however low income and lower middle-income countries have not significantly benefited from trade, and these 
results seem realistic as they are less integrated with the world. Labour force and initial income are main determinants of economic growth in low income countries. For upper middle-income countries, the situation is different, the labour force has not played significant role; initial income and capital formation are major determinants of economic growth. This results also in line with the theory as these upper middle-income countries are in the process of industrialisation.

Table 1: Empirical Results, Dependent Variable: GDPPCG

\begin{tabular}{|l|c|c|c|c|c|c|}
\hline \multicolumn{7}{|c|}{ Unrestricted Model including All Landlocked Countries } \\
\hline Variables & FE & Quantile0.2 & Quantile0.4 & Quantile0.6 & Quantile0.8 & Quantile 1 \\
\hline \multirow{2}{*}{ ININCOM } & $0.27^{* * *}$ & $0.52^{* * *}$ & $0.55^{* * *}$ & $0.49^{* * *}$ & $0.42^{* * *}$ & $0.23^{* * *}$ \\
& $(0.04)$ & $(0.05)$ & $(0.03)$ & $(0.0144)$ & $(0.04)$ & $(0.03)$ \\
\hline \multirow{2}{*}{ TRADE } & $0.02^{*}$ & 0.01 & 0.00 & $0.01^{* * *}$ & $0.02^{* * *}$ & $0.03^{* * *}$ \\
& $(0.01)$ & $(0.01)$ & $(0.01)$ & $(0.003)$ & $(0.01)$ & $(0.01)$ \\
\hline \multirow{2}{*}{ LNBREG } & $2.49^{* *}$ & $0.74^{* *}$ & 0.10 & -0.44 & $-0.9195^{* * *}$ & $\begin{array}{c}4.6106^{* * *} \\
(1.1)\end{array}$ \\
& $(0.33)$ & $(0.17)$ & $(0.09)^{* * *}$ & $(0.21)$ & $(0.3)$ \\
\hline \multirow{2}{*}{ LFG } & $0.87^{* * *}$ & $0.68^{* * *}$ & $0.21^{* *}$ & $-0.1^{* *}$ & 0.11 & $2.78^{* * *}$ \\
& $(0.16)$ & $(0.21)$ & $(0.09)$ & $(0.05)$ & $(0.11)$ & $(0.35)$ \\
\hline \multirow{2}{*}{ FDINFLO } & -0.01 & -0.01 & 0.00 & -0.00 & -0.00 & $-0.03^{* * *}$ \\
& $(0.01)$ & $(0.01)$ & $(0.00)$ & $(0.00)$ & $(0.01)$ & $(0.00)$ \\
\hline \multirow{2}{*}{ GCF } & 0.01 & 0.02 & $0.04^{* *}$ & $0.05^{* * *}$ & $0.08^{* * *}$ & -0.05 \\
& $(0.04)$ & $(0.04)$ & $(0.02)$ & $(0.01)$ & $(0.02)$ & $(0.05)$ \\
\hline \multirow{2}{*}{ Cons } & $-20.1 * * *$ & $-10.22^{* * *}$ & -1.72 & $3.77^{* * *}$ & $7.62^{* * *}$ & $-56.23^{* * *}$ \\
& $(7.87)$ & $(2.34)$ & $(1.17)$ & $(0.60)$ & $(1.41)$ & $(3.48)$ \\
\hline
\end{tabular}

Only for FE Results: F (Prob.) $=26.49(0.00) * * *$

$\mathrm{R}$-squared $=0.20$, Corr $\left(\mathrm{u} \_\mathrm{i}, \mathrm{Xb}\right)=-0.64$

\begin{tabular}{|l|c|c|c|c|c|c|}
\hline \multicolumn{7}{|c|}{ Restricted Model including all Landlocked Countries } \\
\hline Variables & FE & Quantile0.2 & Quantile0.4 & Quantile0.6 & Quantile0.8 & Quantile 1 \\
\hline \multirow{2}{*}{ ININCOM } & $0.29^{* * *}$ & $0.53^{* * *}$ & $0.57^{* * *}$ & $0.53^{* * *}$ & $0.46^{* * *}$ & $0.35^{* * *}$ \\
& $(0.04)$ & $(0.05)$ & $(0.02)$ & $(0.01)$ & $(0.03)$ & $(0.05)$ \\
\hline \multirow{2}{*}{ TRADE } & $0.02^{*}$ & 0.01 & 0.01 & $0.01 * * *$ & $0.02^{* * *}$ & 0.02 \\
& $(0.01)$ & $(0.01)$ & $(0.01)$ & $(0.003)$ & $(0.003)$ & $(0.02)$ \\
\hline \multirow{2}{*}{ LNBREG } & $2.73^{* *}$ & $0.73^{* *}$ & 0.14 & $-0.38^{* * *}$ & $-0.89^{* * *}$ & $4.56^{* * *}$ \\
& $(1.10)$ & $(0.32)$ & $(0.16)$ & $(0.09)$ & $(0.12)$ & $(0.48)$ \\
\hline \multirow{2}{*}{ LFG } & $0.89^{* * *}$ & $0.67 * * *$ & $0.24 * * *$ & -0.04 & $-0.17 * * *$ & $2.70^{* * *}$ \\
& $(0.16)$ & $(0.20)$ & $(0.09)$ & $(0.05)$ & $(0.07)$ & $(0.36)$ \\
\hline \multirow{2}{*}{ FDINFLO } & -0.01 & -0.01 & -0.00 & -0.00 & -0.01 & $-0.03 * * *$ \\
& $(0.01)$ & $(0.01)$ & $(0.01)$ & $(0.00)$ & $(0.01)$ & $(0.01)$ \\
\hline \multirow{2}{*}{ Cons } & $-22.05^{* * *}$ & $-9.78^{* * *}$ & -1.30 & $3.95 * * *$ & $8.98^{* * *}$ & $-56.14^{* * *}$ \\
& $(7.74)$ & $(2.25)$ & $(1.12)$ & $(0.62)$ & $(0.83)$ & $(3.47)$ \\
\hline
\end{tabular}

Only for FE Results: F (Prob.): $37.74(0.00)^{* * *}$,

R-squared $=0.22$, Corr $\left(\mathrm{u} \_\mathrm{i}, \mathrm{Xb}\right)=-0.65$

Note: The Figures in the parenthesis are standard error, ${ }^{*}$ indicates the coefficients are significant at $10 \%,{ }^{* *}$ indicates $5 \%$ and $* * *$ indicates $1 \%$ level of significance.

Source: Author's Calculation. 
14 | The Economic Journal of Nepal (Issue No. 151)

Table 2: Empirical Results, Dependent Variable: GDPPCG

\begin{tabular}{|l|c|c|}
\hline \multicolumn{3}{|c|}{ Restricted Model Excluding High Income Countries } \\
\hline \multicolumn{1}{|c|}{ Variables } & FE: (Prob) & FE (Prob) \\
\hline ININCOM & $0.26^{* * *},(0.04)$ & $0.28^{* * *},(0.04)$ \\
\hline TRADE & $0.05^{* * *},(0.02)$ & $0.04^{* *},(0.16)$ \\
\hline LNBREG & $2.48^{* *},(1.12)$ & $2.62^{* *},(1.19)$ \\
\hline LFG & $0.98^{* * *},(0.16)$ & $0.99^{* * *},(0.18)$ \\
\hline FDINFLO & $0.06,(0.06)$ & $0.05(0.06)$ \\
\hline GCF & $-0.02,(0.04)$ & $-21.81^{* * *},(7.96)$ \\
\hline Cons & $-21.1^{* *},(8.07)$ & F (Prob.) $30.59,(0.00)^{* * *}$ \\
\hline F (Prob.): 23.54 (0.00) *** & \multicolumn{2}{|c|}{ R-squared $=0.22, C o r r\left(u \_i, X b\right)=0.51$} \\
\hline R-squared: 0.22, Corr $\left(u \_i, X b\right)$ & -0.52 &
\end{tabular}

Note: The Figures in the parenthesis are standard error, ${ }^{*}$ indicates the coefficients are significant at $10 \%, \quad * *$ indicates $5 \%$ and $* * *$ indicates $1 \%$ level of significance.

Source: Author's Calculation

The lower panel of Table 1 presents the results for restricted model and shows the robustness as the results are not significantly different than the results of unrestricted model. Table 2 presents the results of restricted and non-restricted model for all landlocked developing countries only [high income countries have been excluded]. The results are consistent with the results of table 1 upper and lower panel of FE column. F-tests for all models are significant and R-squared for panel data with heterogeneous feature are considerably high.

\section{Conclusions and Policy Inferences}

Landlocked countries have additional barrier for the better economic performance compared to other countries. These countries also are in the process to be integrated with world but in slow faced. Initial income is one of the major determinants of economic growth in these countries whether they are poor or rich, however it has more impact in poor countries economic growth compared to rich countries. Trade has a positive role in landlocked countries to foster their growth, but they are not well benefited as desired by the policy makers. Mostly, rich landlocked countries are benefited significantly from trade than the poor. Neighbour countries' economic growth has played the significant role in landlocked countries. As the country's income level increases, it shifts to industrialisation so that capital formation is important compared to labour force until the economy converges to developed economy.

The empirical results support all 3 major hypothesis i.e. trade openness has significant positive role in landlocked countries, however it is different in poor countries' case; neighbours' economic growth significantly impacts to the economic growth of these countries; and initial income has more role to play in low income countries compared to rich countries. From quantile regression results, Landlockedness does not destine countries to remain poor even with high trade cost, in fact, appropriate economic policy can overcome the constraints by Landlockedness.

The major policy inference from this study has two folds. The first is that trade has a significant 
role to play and trade growth nexus is clearly visible even in landlocked developing countries. Therefore, the special focus is needed to integrate the landlocked least developed countries with world so that they can benefit from the trade and globalisation in the future. The second is that neighbours' economic growth is important part of growth in most of the landlocked countries, so the programs to suit this real scenario need to be developed and implemented.

\section{References}

Athukorala, P. (2011). Production networks and trade patterns in East Asia: Regionalization or globalization? Asian Economic Papers, 10(1), 65-95.doi:doi:10.1162/ASEP_a_00045

Awokuse, T. O. (2008). Trade openness and economic growth: Is growth export-led or importled? Applied Economics, 40(2), 161 - 173.

Barro, R. J. (1999). Determinants of economic growth: A cross-country empirical study, (2 ed.): The MIT Press, London, England.

Bhagawati, J. (2000). The 'Miracle' that did happen: Understanding East Asia in comparative perspective. Cambridge, MAS: MIT Press.

Billmeier, A. \& Nannicini, T. (2007). Trade openness and growth: Pursuing empirical glasnost. SSRN e-library.

Buchinsky, M. (1998). Recent advances in quantile regression models: A practical guideline for empirical research. The Journal of Human Resources, 33(1), 88-126.

Clemens, M. A., \& Williamson, J. G. (2004). Why did the tariff-growth correlation change after 1950? Journal of Economic Growth, 9(1), 5-46.

Collier, P. (2007). The bottom billion: Why the poorest countries are failing and what can be done about it, Oxford University Press.

Dufrenot, G., Mignon, V., \& Tsangarides, C. (2010). The trade-growth nexus in the developing countries: A quantile regression approach. Review of World Economics, 146(4), 731-761.

Foreman-Peck, J. (1995). A model of later nineteenth century European economic development. Revista de historia economica, XIII(3), 441-472.

Gallup, J. L., Sachs, J. D., \& Mellinger, A. D. (1999). Geography and economic development. International Regional ScienceReview, 22(2), 179-232.doi:10.1177/016001799761012334

Hailou, F. (2007). Spatial constraints, trade and growth: Evidence from sub-Saharan Africa. Howard University, Ph.D. Dissertation, Retrieved from http://search.proquest.com/docvi ew/304848866? accountid $=8330$

Islam, N. (1995). Growth empirics: A panel data approach. The Quarterly Journal of Economics, 110(4), 1127-1170.

Koenker, R., \& Bassett, G., Jr. (1978). Regression quantiles. Econometrica, 46(1), 33-50. 
16 | The Economic Journal of Nepal (Issue No. 151)

Kravis, I. B. (1970). Trade as a handmaiden growth: Similarities between the nineteenth and twentieth centuries. Economic journal, 80(320), 850-872.

MacKellar, L., Worgotter, A. and W. Julia. (2000). Economic development problems of landlocked countries. Transition Economics Series, 14, Institute for Advanced Studies.

Moral-Benito, E. (2009). Determinants of economic growth: A bayesian panel data approach. World Bank Policy Research Working Paper (4830), 1-33.

Obstfeld, M., \& Rogoff, K. (2000). The six major puzzles in international macroeconomics: Is there a common cause? NBER Macroeconomics Annual, 15 (ArticleType: research-article/Full publication date: 2000/Copyright (C) 2000 The University of Chicago Press), 339-390.

Paudel, R. C. (2013). Growth and export performance of developing countries: Is landlockedness destiny?, Ph.D. dissertation, The Australian National University, Canberra, Australia.

Paudel, R. C. (2014). Export performance in developing countries: A comparative perspective: Arndt-Corden Department of Economics, Crawford School of Economics and Public Policy, Australian National University, Canberra.

Paudel, R. C. (2016). Liberalization reform and export performance of India. Journal of Economics and Economic Education Research, 17(3), 201.

Paudel, R. C., \& Jayanthakumaran, K. (2009). Financial liberalization and performance in Sri Lanka: The ARDL Approach. South Asia Economic Journal, 10(1), 127-156.

Ram, R. (1985). Exports and economic growth: Some additional evidence. Economic Development and Cultural Change, 33(2), 415-425.

Sachs, J. D. (2008). The strategy of economic development common wealth economics for a crowded planet, The Penguin Press, New York.

Temple, J. (1998). Initial conditions, social capital and growth in Africa. Journal of African Economies, 7(3), 309-347.

UNCTAD. (2006). Landlocked Developing Countries. Retrieved from New York and Geneva:

Vamvakidis, A. (2002). How robust is the growth-openness connection? Historical Evidence. Journal of Economic Growth, 7(1), 57-80. doi:10.1023/a:1013418610712

Voivodas, C. S. (1973). Exports, foreign capital inflow and economic growth. Journal of International Economics, 3(4), 337-349.

Waldauer, C., Zahka, W. J., \& Pal, S. (1996). Kautilya's arthashastra: A neglected precursor to classical economics. Indian Economic Review, XXXI(1), 101-108.

Weiss, J. (1999). Trade reform and manufacturing performance in Mexico: From import substitution to dramatic export growth. Journal of Latin American Studies, 31, 151-166.

World Bank. (2011). World Development Indicators. Retrieved 07/05/2011, from World Bank, Access 07/05/2011 http://data.worldbank.org/data-catalog 